\title{
Biosensor for Neurotransmitter L-Glutamic Acid Designed for Efficient Use of L-Glutamate Oxidase and Effective Rejection of Interference
}

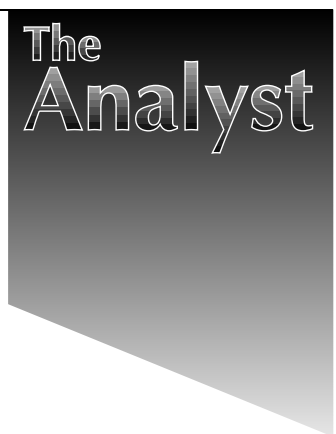

\author{
Michael R. Ryan, John P. Lowry and Robert D. O'Neill* \\ Department of Chemistry, University College Dublin, Belfield, Dublin 4, Ireland. \\ E-mail:Robert.ONeill@UCD.ie
}

\begin{abstract}
An amperometric biosensor for L-glutamic acid (Glu) was constructed by the adsorption and dip coating of L-glutamate oxidase (GluOx, $200 \mathrm{U} \mathrm{ml}^{-1}$ phosphate buffer, $\mathrm{pH}$ 7.4) onto 60- $\mu \mathrm{m}$ radius Teflon-coated Pt wire (1 $\mathrm{mm}$ exposed length). The enzyme was then trapped on the surface by electropolymerisation of $o$-phenylenediamine that also served to block electroactive interference. This procedure afforded electrodes with similar substrate sensitivity compared with the classical approach of immobilising enzyme from a solution of monomer, and represents an approximately 10000 -fold increase in the yield of biosensors from a batch of enzyme. A number of strategies were examined to enhance the sensitivity and selectivity of the Pt/PPD/GluOx sensors operating at $0.7 \mathrm{~V}$ versus SCE. Pre-coating the Pt with lipid and incorporation of the protein bovine serum albumin into the polymer matrix were found to improve the performance of the electrode. The sensors had a fast response time, high sensitivity to Glu, with an LOD of about $0.3 \mu \mathrm{mol} \mathrm{I}^{-1}$, and possessed selectivity characteristics suggesting that monitoring Glu in biological tissues in vivo may be feasible.
\end{abstract}

Keywords: Enzyme-modified electrode; polymer-modified electrode; poly(o-phenylenediamine); ascorbic acid interference; amperometry; brain glutamate

L-Glutamate $(\mathrm{Glu})$ is a ubiquitous excitatory amino acid neurotransmitter in the mammalian CNS, playing a major role in a wide variety of brain functions. ${ }^{1-3}$ Glu concentrations in brain extracellular fluid (ECF) in vivo have been estimated in the $10 \mu \mathrm{mol} 1^{-1}$ region using a variety of microdialysis techniques and detection systems, ${ }^{4-8}$ and a number of valuable studies on brain Glu have been reported using these methodologies. ${ }^{1,9-12}$ The dialysis approach to monitoring brain chemistry has certain restrictions, however, such as limited time resolution and depletion of the ECF. As an alternative approach to detecting species in the ECF, implantable amperometric biosensors provide a continuous signal ${ }^{13}$ with significantly less depletion. ${ }^{14}$

A number of sensor types have been developed for the measurement of Glu based on a variety of metabolic enzymes. ${ }^{15-20}$ Attention has focused mainly on the use of L-glutamate oxidase (GluOx) that has FAD as the redox centre and molecular oxygen as a co-substrate, ${ }^{21}$ producing hydrogen peroxide that can be detected amperometrically $19,20,22-30$ or spectroscopically. ${ }^{31,32}$ The oxidative deamination catalysed by GluOx ${ }^{21}$ can be represented by the following steps:

L-Glutamate $+\mathrm{H}_{2} \mathrm{O}+$ GluOx/FAD $\rightarrow \alpha$-ketoglutarate $+\mathrm{NH}_{3}+$

$$
\mathrm{GluOx} / \mathrm{FADH}_{2}
$$

$$
\mathrm{GluOx} / \mathrm{FADH}_{2}+\mathrm{O}_{2} \rightarrow \mathrm{GluOx} / \mathrm{FAD}+\mathrm{H}_{2} \mathrm{O}_{2}
$$

The $\mathrm{H}_{2} \mathrm{O}_{2}$ produced (reaction 2) can be electro-oxidised and this is generally carried out amperometrically at relatively high applied potentials (reaction 3).

$$
\mathrm{H}_{2} \mathrm{O}_{2} \rightarrow \mathrm{O}_{2}+2 \mathrm{H}^{+}+2 \mathrm{e}
$$

An important problem in the use of enzyme-modified electrodes in biological media is interference by endogenous electroactive reducing agents, especially ascorbic acid (AA). This problem has been resolved, to a great extent, by the use of electrosynthesised polymers, such as poly(o-phenylenediamine) (PPD), that block access to the electrode surface of even relatively small organic molecules ${ }^{33-39}$ without affecting sensitivity to hydrogen peroxide, ${ }^{40}$ and a Pt/PPD/GluOx sensor has been reported. ${ }^{17,24}$

The classical procedure for incorporating oxidase enzymes into a protecting polymer film has been to co-deposit the enzyme and polymer onto the electrode from a solution of the enzyme and monomer. ${ }^{33-39}$ This is convenient and effective but is very cost-inefficient for expensive enzymes such as GluOx. The aim of this work was to develop a more efficient procedure for producing Pt/ PPD/GluOx sensors with high sensitivity to Glu. Since the intended application for these biosensors is monitoring Glu in brain ECF, where the concentration of AA is about $500 \mu \mathrm{mol} 1^{-1,41,42}$ special attention was paid to blocking interference by reducing agents.

\section{Materials and Methods}

\section{Reagents and Solutions}

The enzyme L-glutamate oxidase ${ }^{21}$ (GluOx from Streptomyces sp. X-119-6, EC 1.4.3.11, $200 \mathrm{U} \mathrm{ml}^{-1}$ in $20 \mathrm{mmol}^{-1}$ potassium phosphate buffer, $\mathrm{pH}$ 7.4) was obtained as a generous gift from Yamasa Corporation, Chiba, Japan, and stored at $-20{ }^{\circ} \mathrm{C}$. The enzyme glucose oxidase (GOx) from Aspergillus niger (EC 1.1.3.4, Type VII-S) was from Sigma Chemical Co. (St. Louis, MO, USA). The lipid phosphatidylethanolamine (PEA, Type II-S) and bovine serum albumin (BSA, fraction V) were also obtained from Sigma. Stearic acid (STA), Nafion (NAF, $1100 \mathrm{EW}, 5 \%$ solution in alcohol) and D-glucose were obtained from Aldrich (Milwaukee, WI, USA). All chemicals, including $o$-phenylenediamine (PD, Sigma), L-glutamic acid (Glu, Sigma), L-glutamine (Sigma) and L-ascorbic acid (AA, Aldrich), were used as supplied.

Solutions of PD (20-400 mmol $\left.\mathrm{l}^{-1}\right)$ were made up in $10 \mathrm{ml}$ of a phosphate-buffered saline solution (PBS) with dissolution achieved by sonication at $25{ }^{\circ} \mathrm{C}$ for $25 \mathrm{~min}$. Stock solutions of $100 \mathrm{mmol} 1^{-1}$ Glu and AA were prepared in doubly distilled water and $0.01 \mathrm{~mol} 1^{-1} \mathrm{HCl}$, respectively, and stored at $4{ }^{\circ} \mathrm{C}$. All experiments were carried out in vitro in PBS ( $\mathrm{pH} 7.4)$ that consisted of $0.15 \mathrm{~mol} \mathrm{l}^{-1} \mathrm{NaCl}$ (Merck, Poole, UK), 0.04

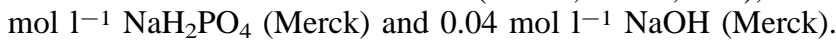
Solutions were kept refrigerated when not in use.

\section{Instrumentation and Software}

Experiments were microcomputer controlled with data acquisition achieved using a Biodata Microlink interface, a low-noise, low-damping potentiostat (Biostat II, Electrochemical and 
Medical Systems, Newbury, UK) and in-house software. The linear and non-linear regression analyses were performed using the graphical software package Prism (GraphPad Software, San Diego, CA, USA). All experiments were done in a $25 \mathrm{ml}$ glass cell at $25{ }^{\circ} \mathrm{C}$, using a standard three-electrode set-up with a saturated calomel electrode (SCE) as the reference and a silver wire in a glass sheath as the auxiliary electrode.

\section{Preparation of the Working Electrodes}

All the working electrodes were based on Pt cylinders $(60 \mu \mathrm{m}$ radius) prepared by cutting strips of Teflon-coated platinum wire, sliding the Teflon along the wire to expose about $1 \mathrm{~mm}$ of metal and sealing the Teflon rim with cyanoacrylate adhesive. The exposed metal was then dipped a number of times into $20 \mu \mathrm{l}$ of a buffered solution of GluOx or GOx to deposit the enzyme. The number of dips varied (see below) but in all cases the first dip was left in the enzyme solution for 5 min to allow adsorption of the enzyme to occur. ${ }^{17,24,43,44}$ For all subsequent dips the electrode was immersed in the enzyme solution, removed immediately and allowed to dry for $5 \mathrm{~min}$.

The enzyme-coated wire was introduced into PBS containing the monomer (20-400 $\left.\mathrm{mmol} \mathrm{l}^{-1} \mathrm{PD}\right)$ and, in some cases, the non-enzyme protein BSA $\left(5 \mathrm{mg} \mathrm{ml}^{-1}\right), 45$ and electropolymerisation carried out immediately at $0.7 \mathrm{~V}$ versus SCE. The polymerisation time for this self-sealing process was $30 \mathrm{~min}$, unless stated otherwise. In some cases the lipid PEA ${ }^{45,46}$ or fatty acid STA was used to coat the Pt before enzyme deposition. This procedure involved dipping the bare $\mathrm{Pt}$ wire a number of times into PEA or STA dissolved in chloroform $\left(100 \mathrm{mg} \mathrm{ml}^{-1}\right)$, allowing the solvent to evaporate each time (1 min).

Calibrations were performed amperometrically at $0.7 \mathrm{~V}$ versus SCE in quiescent air-saturated PBS for glucose in the range $0-10 \mathrm{mmol} \mathrm{l}^{-1}$ and for Glu in the ranges $0-100 \mu \mathrm{mol} \mathrm{l}^{-1}$ (for LOD and linearity studies) and 0-10 $\mathrm{mmol} \mathrm{l}^{-1}$ (for $K_{\mathrm{m}}$ and $V_{\max }$ determinations). Calibrations for interfering substances were also carried out under the same conditions except $\mathrm{N}_{2}$ saturated buffer was used: ascorbate (AA, 0-1 mmol $1^{-1}$ ), dopamine (DA, 0-10 $\mu$ mol 1-1), 3,4-dihydroxyphenylacetic acid (DOPAC, 0-100 $\mu \mathrm{mol} \mathrm{l}^{-1}$ ) and uric acid (UA, 0-100 $\mu \mathrm{mol}$ $\left.1^{-1}\right)$. Air-saturated solutions were used in the determination of L-glutamine interference $\left(0-1 \mathrm{mmol} \mathrm{l}^{-1}\right)$.

Since the resting level of AA in brain ECF has been estimated ${ }^{41,42}$ at $500 \mu \mathrm{mol}^{-1}$ and because the AA response at PPD-modified electrodes is non-linear (decreasing with higher concentrations), ${ }^{40,45} 500 \mu \mathrm{mol} \mathrm{1^{-1 }}$ AA responses were determined by adding $500 \mu \mathrm{mol} 1^{-1}$ AA to $500 \mu \mathrm{mol}^{-1} \mathrm{AA}$ in PBS, corresponding to a doubling of the baseline ECF concentration of AA. This approach to quantifying interference by AA is further justified by the finding that doubling the concentration of AA in the ECF in vivo had no detectable effect on the current recorded with a Pt/PPD/GOx sensor, even several days after implantation. 39

\section{Data Analysis}

Calibration plots for Glu were generated by plotting averaged steady-state currents versus substrate concentration and fitting the data using non-linear regression to obtain the apparent Michaelis-Menten constants $V_{\max }(\mathrm{nA})$ and $K_{\mathrm{m}}\left(\mathrm{mmol} \mathrm{l}^{-1}\right)$. Linear regression was used for the $0-100 \mu \mathrm{mol} 1^{-1}$ data to determine sensitivity in the linear response region and correlation coefficients.

The selectivity coefficient of each electrode type for Glu vs. AA $\left(S_{\mathrm{AA}}\right)$ was calculated for individual sensors using eqn. (4), ${ }^{47}$ and then averaged.

$$
S_{\mathrm{AA}}=\frac{\left|I_{\mathrm{Glu}}\right|-\left|I_{\mathrm{AA}}\right|}{\left|I_{\mathrm{Glu}}\right|} \times 100 \%
$$

The $\left|I_{\mathrm{Glu}}\right|$ and $\left|I_{\mathrm{AA}}\right|$ used here were the absolute steady-state currents for $10 \mu \mathrm{mol} 1^{-1}$ Glu and $500 \mu \mathrm{mol} 1^{-1} \mathrm{AA}$, respectively. The range of interest for $S_{\mathrm{AA}}$ is $0-100 \%$ : $0 \%$ corresponds to $I_{\mathrm{Glu}}$ and $I_{\mathrm{AA}}$ being equal; negative values reflect interference current greater than the signal for the target substrate; and $100 \%$ corresponds to no AA signal for an increase in concentration of $500 \mu \mathrm{mol} \mathrm{l}^{-1}$.

All data are reported as mean $\pm s$ with $n$ being the number of electrodes. Unpaired, two-tailed $t$-tests were used to compare responses for different electrode designs. Values of $p<0.05$ were taken to indicate statistically significant differences between groups of electrodes.

\section{Results and Discussion \\ Pt/PPD/GOx Electrodes}

Previous studies on the immobilisation of enzymes into the nonconducting form of the polymer PPD have involved either electropolymerisation from a solution of the enzyme plus monomer ${ }^{33-39}$ or from a monomer solution using electrodes with pre-adsorbed enzyme. ${ }^{17,24}$ The former approach uses large amounts of enzyme, typically $5 \mathrm{mg} \mathrm{ml}^{-1}$, whereas the latter leads to sensors with relatively poor sensitivity for substrate. ${ }^{17}$ To develop a sensor for Glu, using the expensive enzyme GluOx, we investigated here the use of 'dip coating' to deposit enzyme on the electrode surface prior to electropolymerisation in solution of monomer, PD.

To compare the effectiveness of the dip coating approach to the standard co-deposition of enzyme and polymer from solution, we used GOx as a model enzyme. Because our sensor development programme is motivated by applications in mammalian brain, we have used concentrations appropriate to this environment in many of the experiments.

The average current density for $500 \mu \mathrm{mol} 1^{-1}$ glucose, recorded amperometrically at $0.7 \mathrm{~V}$ versus SCE with $\mathrm{Pt} / \mathrm{PPD} /$ GOx sensors produced by polymerisation in a 5-ml solution containing $5 \mathrm{mg} \mathrm{ml}^{-1} \mathrm{GOx}$ and $300 \mathrm{mmol} \mathrm{l}^{-1} \mathrm{PD}$, was $1.8 \pm$ $0.9 \mu \mathrm{A} \mathrm{cm}^{-2}(n=13)$; this combination of enzyme and monomer has been shown previously to be optimal for these conditions. ${ }^{40}$ The currents for $500 \mu \mathrm{mol} 1^{-1}$ glucose recorded under the same conditions with sensors produced by different numbers of dip coatings using a $200 \mathrm{U} \mathrm{ml}^{-1} \mathrm{GOx}$ solution (to mimic the GluOx solution supplied) followed by polymerisation in $300 \mathrm{mmol} \mathrm{1}^{-1} \mathrm{PD}$ were: $1 \mathrm{dip}, 0.7 \pm 0.1 \mathrm{nA}(n=2)$; 2 dips, $3.8 \pm 2.3 \mathrm{nA}(n=3) ; 5$ dips, $5.1 \pm 2.0 \mathrm{nA}(n=3) ; 10$ dips, $10.9 \pm 4.8 \mathrm{nA}(n=3)$; and 20 dips, $3.1 \pm 1.6 \mathrm{nA}(n=2)$. There was a maximum in the response for 10 dips that corresponds to a current density of $2.8 \pm 1.3 \mu \mathrm{A} \mathrm{cm}^{-2}(n=$ $3)$.

Thus, the response of sensors produced by the dip coating method was at least as good as the classical co-deposition procedure. In addition, the reproducibility of the sensors' sensitivity to Glu (as measured by the coefficient of variation) was the same for the two methods of production.

\section{Pt/PPD/GluOx Electrodes}

Having established that GOx could be successfully immobilised by dip coating followed by polymerisation, the procedure was applied to GluOx. The amperometric responses at $0.7 \mathrm{~V}$ versus SCE for $10 \mu \mathrm{mol} 1^{-1} \mathrm{Glu}$, recorded with sensors produced by different numbers of dip coatings using a $200 \mathrm{U} \mathrm{ml}^{-1} \mathrm{GluOx}$ solution followed by polymerisation in $300 \mathrm{mmol} \mathrm{l}^{-1} \mathrm{PD}$, were: $1 \mathrm{dip}, 0.62 \pm 0.02 \mathrm{nA}(n=2) ; 2$ dips, $0.59 \pm 0.14 \mathrm{nA}(n=2)$; 5 dips, $0.78 \pm 0.24(n=5)$; and 10 dips, $0.66 \pm 0.35(n=5)$. 
Surprisingly, and in contrast to GOx, there was no distinct peak in the current versus number of dips. Five dips was chosen as the standard for further experiments as this gave the largest (albeit not statistically different) response; this sensor is represented as $\mathrm{Pt} / \mathrm{PPD} / \mathrm{GluOx}$. Approximately 60 sensors were made from each $20 \mu \mathrm{l}$ aliquot of enzyme, representing an approximately 10000 -fold increase in the efficiency of GluOx immobilisation compared with the co-deposition method.

The sensitivity of the sensor corresponds to a current density of $0.20 \pm 0.07 \mu \mathrm{A} \mathrm{cm}^{-2}(n=5)$ for $10 \mu \mathrm{mol} 1^{-1} \mathrm{Glu}$ and compares very favourably with other biosensors for Glu. ${ }^{16,17,20}$ These basic sensors exhibited Michaelis-Menten kinetics with a $V_{\max }$ of $6.2 \pm 0.9 \mathrm{nA}$ and a $K_{\mathrm{m}}$ of $0.25 \pm 0.10 \mathrm{mmol} \mathrm{l}^{-1}, n=$ 4 , the latter value being the same as that observed for GluOx in solution. ${ }^{21}$

Considering the sensitivity of Pt to AA, ${ }^{40}$ bare cylinders of the dimensions used here would be expected to give about 400 $\mathrm{nA}$ for $500 \mu \mathrm{mol} 1^{-1}$ AA. The actual response to this concentration of AA determined using $\mathrm{Pt} / \mathrm{PPD} / \mathrm{GluOx}$ sensors was only $0.8 \pm 0.3 \mathrm{nA}(n=5)$, indicating that the PPD film is blocking access to the Pt surface quite efficiently. This barrier, however, is not sufficient for neurochemical applications since the selectivity coefficient for $10 \mu \mathrm{mol} 1^{-1}$ Glu versus 500 $\mu \mathrm{mol} 1^{-1} \mathrm{AA}, S_{\mathrm{AA}}$ (see eqn. 4$)$, was $-11 \pm 40 \%(n=5)$, i.e., the current for AA was similar to that for Glu at these concentrations.

\section{Pt/PEA/PPD/GluOx Electrodes}

The improved selectivity afforded by undercoating the enzyme layer with large molecules, such as PEA, ${ }^{45,46}$ is due to the fact that different sites are involved in the oxidation of interference molecules (Pt surface) and the substrate (enzyme) (see Fig. 1). Thus, PEA efficiently blocks access to the Pt surface for AA, say, but does not hinder access of Glu to the enzyme (reaction 1). Furthermore, the sensitivity of $\mathrm{Pt}$ to the small $\mathrm{H}_{2} \mathrm{O}_{2}$ molecule (reaction 3 ) is not affected by macromolecules on the metal surface. ${ }^{40}$

Pre-coating Pt disks with the lipid PEA by drop coating from chloroform before electropolymerisation has been shown previously to enhance the interference blocking properties of biosensors. ${ }^{45,46}$ Since drop coating also led to a slower response time ${ }^{45}$ the dip coating method was investigated here as an alternative means of depositing PEA onto bare Pt cylinders before immobilisation of the GluOx. The effect of 0-10 dips in a PEA solution $\left(100 \mathrm{mg} \mathrm{ml}^{-1}\right.$ in chloroform) on the response of the sensor to $10 \mu \mathrm{mol}^{1^{-1}} \mathrm{Glu}$ and $500 \mu \mathrm{mol} 1^{-1}$ AA was determined.

The presence of lipid had no significant effect on the Glu response. Increasing the amount of PEA on the surface, however, decreased the AA response and had a maximum effect for 5 dips $(0.33 \pm 0.03 \mathrm{nA}, n=3, p<0.05$, compared with no PEA, $0.78 \pm 0.29, n=5$ ). The observation that 10 dips was less effective than 5 dips may be caused by inhibition of PPD formation at this higher surface coverage of PEA. Although the characteristics of the $\mathrm{Pt} / \mathrm{PEA} / \mathrm{PPD} / \mathrm{GluOx}$ sensor were im- proved by the PEA $\left(S_{\mathrm{AA}}=43 \pm 10 \%, n=3\right.$ ), the selectivity of the electrode was still not considered adequate for neurochemical analysis in vivo.

\section{Pt/PEA/PPD/BSA/GluOx Electrodes}

The ability of non-conducting PPD films formed at neutral $\mathrm{pH}$ (about $10 \mathrm{~nm}$ thick ${ }^{34,48}$ ) to block interference appears to be enhanced by the incorporation of protein (enzyme and nonenzyme) into the polymer matrix; 40,45 both electrochemical and electron microscopy data suggest that PPD films are more compact when formed by electropolymerisation in monomer solution containing protein. ${ }^{40}$ Although enzyme is present on the $\mathrm{Pt}$ for the sensors described here so far, protein was not present in the polymerisation solution. Electropolymerisation in solutions of PD and BSA $\left(5 \mathrm{mg} \mathrm{ml}^{-1}\right.$, a concentration that has been shown to be optimal for our conditions ${ }^{45}$ ) was therefore carried out in attempts to improve the selectivity further.

The data in Table 1 show that there was indeed a significant ( $p<0.01)$ improvement in $S_{\mathrm{AA}}(83 \pm 9 \%, n=9)$ when BSA was incorporated into the PPD sensor. Surprisingly, this improvement was due to both an increase in the Glu current and a decrease in the AA response. Thus, the co-deposition of protein with the polymer may protect some GluOx molecules from inactivation by the polymerisation process in a similar way to that in which BSA protects enzymes during cross-linking with glutaraldehyde. 49

A schematic illustration of a Pt/PEA/PPD/BSA/GluOx electrode, based on both structural and electrochemical data, is shown in Fig. 1. The thickness of the non-conducting PPD film formed under neutral conditions (about $10 \mathrm{~nm}^{34,48}$ ) is similar to the diameter of oxidases such as $\mathrm{GOx}^{39}$ (about $9 \mathrm{~nm}, 180 \mathrm{kD}$ ) and GluOx (about $140 \mathrm{kD}^{21}$ ), whereas the size of the smaller BSA molecule (about $70 \mathrm{kD}$ ) is not critical. One might expect, therefore, that the binding site of a population of GluOx molecules would not be hindered by the polymer. ${ }^{33}$ This view is supported by the reported rapid response times (e.g., $1 \mathrm{~s}^{34}$ or $<10 \mathrm{~s}^{39,40,45}$ ) for glucose at PPD/GOx electrodes and for Glu at PPD/GluOx sensors (see Fig. 2, below). Although PPD efficiently blocks access to the metal for molecules the size of AA, Glu, glucose, etc., the small $\mathrm{H}_{2} \mathrm{O}_{2}$ molecules produced enzymatically (reactions 1 and 2) can diffuse to the Pt surface to be oxidised 40 (reaction 3). The PEA underlying the enzyme layer provides additional blocking of the $\mathrm{Pt}$ surface for interferences, such as AA, but does not hinder access of Glu to the enzyme (reaction 1).

\section{Other Modifications of the Sensor}

Stearic (octadecanoic) acid (STA) has been used in the past in attempts to block interference by AA in neurotransmitter detection using carbon electrodes. ${ }^{50,51}$ The rationale is that the presence of carboxylate anions on the surface (at $\mathrm{pH}$ 7.4) should reject AA anions by electrostatic repulsion. We therefore replaced the zwitterionic PEA with STA (5 dips in $100 \mathrm{mg} \mathrm{ml}^{-1}$ chloroform) in the dip coating of the Pt prior to enzyme

Table 1 Average $\pm s$ Glu and AA currents calculated from individual calibrations in PBS (pH 7.4) at +0.7 V versus SCE, the corresponding selectivity coefficients $\left(S_{\mathrm{AA}}\right.$, see eqn. 4$) \pm s$ and LOD $\pm s$. Number of dip coatings of each modifier was: phosphatidylethanolamine (PEA, $100 \mathrm{mg}$ ml -1 in chloroform: 5), glutamate oxidase (GluOx, $200 \mathrm{U} \mathrm{ml}^{-1}$ phosphate buffer: 5), stearic acid (STA, $100 \mathrm{mg} \mathrm{ml}^{-1}$ in chloroform: 5) and Nafion (NAF, $1 \%$ alcohol solution: 1)

Electrode design

$\mathrm{Pt} / \mathrm{PPD} / \mathrm{GluOx}, n=5$

Pt/PEA/PPD/GluOx, $n=3$

$\mathrm{Pt} / \mathrm{PEA} / \mathrm{PPD} / \mathrm{BSA} / \mathrm{GluOx}, n=9$

Pt/STA/PPD/BSA/GluOx, $n=6$

$\mathrm{Pt} / \mathrm{NAF} / \mathrm{PPD} / \mathrm{BSA} / \mathrm{GluOx}, n=3$

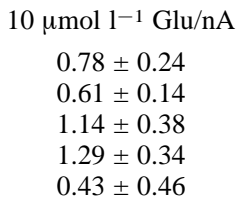

$0.43 \pm 0.46$

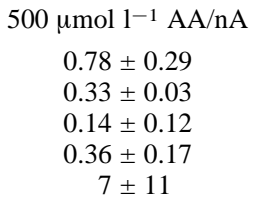

$$
\begin{gathered}
S_{\mathrm{AA}}(\%) \\
-11 \pm 40 \\
43 \pm 10 \\
83 \pm 9 \\
71 \pm 10
\end{gathered}
$$$$
<-100
$$

LOD/ $\mu \mathrm{mol} 1^{-1}$

$0.35 \pm 0.33$

$0.23 \pm 0.33$

$0.27 \pm 0.21$

$0.15 \pm 0.09$

$1.5 \pm 1.3$ 
deposition and subsequent polymerisation. The data in Table 1 show that the replacement of blocking agent had the opposite effect to that expected, decreasing the selectivity coefficient ( $p$ $<0.05)$ due to a larger AA response $(p<0.02)$. It appears therefore that the hydrophobic properties of these molecules are equally, if not more, important than electrostatic factors for blocking interference.

The perfluorinated polysulfonic acid Nafion has been used even more widely than STA to block AA interference in

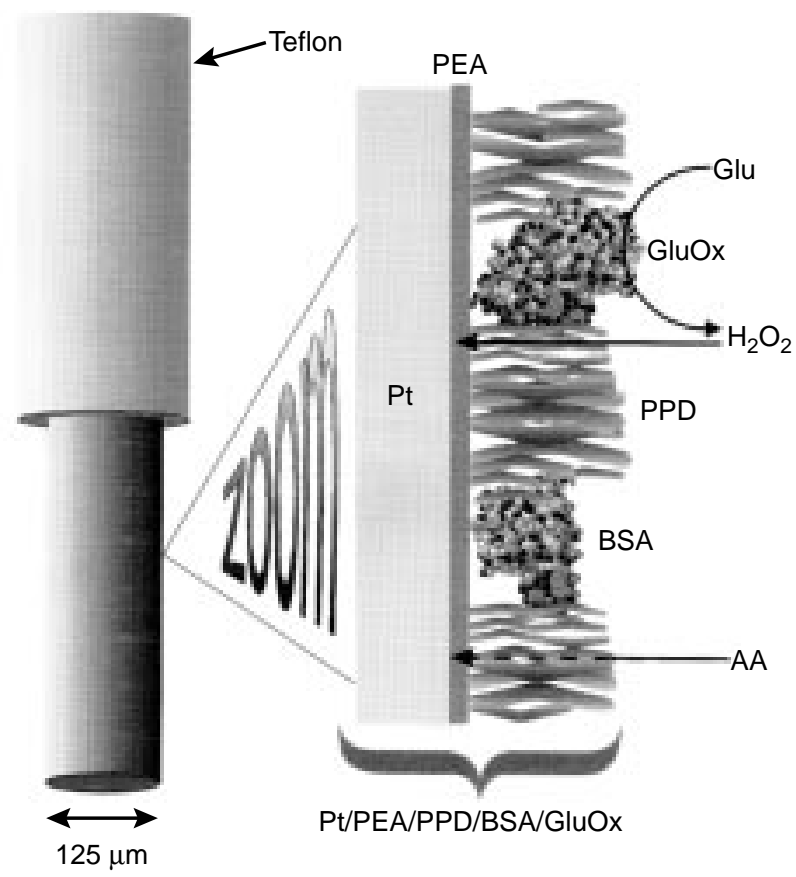

Fig. 1 Schematic illustration of a Pt/PEA/PPD/BSA/GluOx sensor fabricated by: dip coating the lipid phosphatidylethanolamine (PEA) from a chloroform solution onto bare $\mathrm{Pt}$; adsorption and dip coating of L-glutamate oxidase (GluOx) from an aqueous buffer onto the PEA layer; and electrosynthesis of the non-conducting form of polyphenylenediamine (PPD) in a PBS solution ( $\mathrm{pH}$ 7.4) containing monomer and bovine serum albumin (BSA). See text for the rationale of the scheme. The GluOxcatalysed oxidative deamination of L-glutamate (Glu) yielding $\mathrm{H}_{2} \mathrm{O}_{2}$ is given in the text by reactions 1 and 2 . The small $\mathrm{H}_{2} \mathrm{O}_{2}$ molecules can diffuse easily to the $\mathrm{Pt}$ surface to be electro-oxidised (reaction 3) with a characteristic fast response time (see Fig. 2). Access to the metal by larger electroactive species, such as ascorbic acid (AA), is severely restricted by the PPD, PEA and proteins, with a correspondingly small and slow response (see Fig. 2, inset)

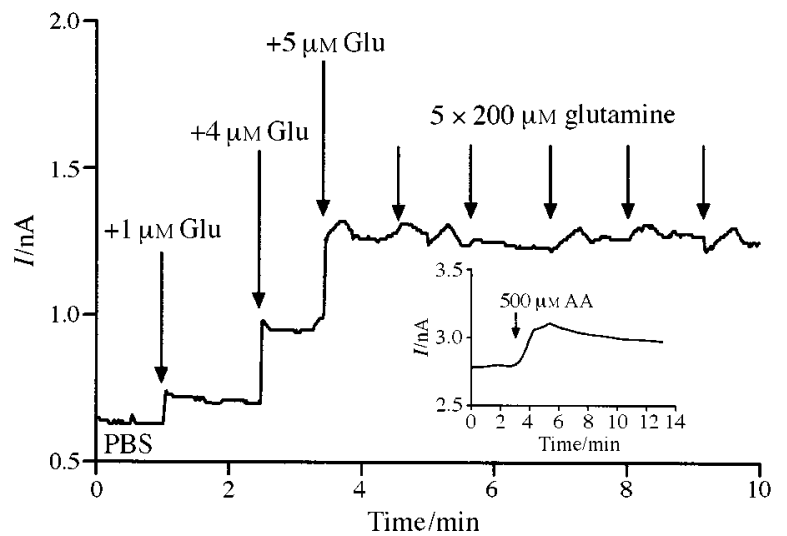

Fig. 2 Example of amperometric calibration data for glutamate (Glu, $0-10 \mu \mathrm{mol}^{-1}$ ) recorded at $0.7 \mathrm{~V}$ versus $\mathrm{SCE}$ with a Pt/PEA/PPD/BSA/ GluOx electrode (see Fig. 1), also showing the lack of sensor response to 5 injections of $+200 \mu \mathrm{mol}^{-1}$ glutamine. The inset shows an example of a $500 \mu \mathrm{mol}^{-1}$ AA response (see Table 1 for data). neurotransmitter detection. ${ }^{52}$ However, the replacement of PEA in the sensor using 1 dip of a $1 \%$ solution of Nafion in alcohol had a catastrophic effect on $S_{\mathrm{AA}}$, decreasing the Glu signal and increasing the AA current (see Table 1). Nafion may therefore inhibit both the deposition of GluOx on the electrode and the formation of PPD.

As final modifications of the sensor we investigated the effect of monomer concentration and polymerisation time. At least four sensors were made for each monomer concentration: 20, $100,200,300$ and $400 \mathrm{mmol} \mathrm{l}^{-1} \mathrm{PD}$. The value of $S_{\mathrm{AA}}$ rose steadily from $-360 \pm 250 \%(n=4)$ at $20 \mathrm{mmol} 1^{-1} \mathrm{PD},-50 \pm$ $50 \%(n=4)$ at $100 \mathrm{mmol} \mathrm{l}^{-1}, 15 \pm 30 \%(n=4)$ at $200 \mathrm{mmol}$ $1^{-1}$ to a peak value of $83 \pm 9 \%(n=9)$ at $300 \mathrm{mmol} \mathrm{l}^{-1} \mathrm{PD}$, and declined again to $66 \pm 27 \%(n=4)$ at $400 \mathrm{mmol} \mathrm{l}^{-1}$, a concentration close to saturation. The $S_{\mathrm{AA}}$ value was also sensitive to polymerisation time in $300 \mathrm{mmol} \mathrm{l}^{-1}$ PD solutions, mainly due to a decrease in AA response for longer times: $12 \pm$ $16 \%$ ( $1 \mathrm{~min}, n=3) ;-10 \pm 100 \%$ ( $5 \mathrm{~min}, n=3) ; 86 \pm 9 \%$ (15 $\min , n=2)$; and $83 \pm 9 \%(30 \mathrm{~min}, n=9)$. Thus, although the polymerisation current associated with the formation of the selfsealing, non-conducting PPD (about $10 \mathrm{~nm}$ thick ${ }^{34,48}$ ) falls rapidly to low steady-state values, it appears that $15 \mathrm{~min}$ are needed to minimise any small pores in the polymer matrix ${ }^{40}$ (see Fig. 1).

\section{Other Characteristics of the Pt/PEA/PPD/BSA/GluOx Sensor}

The sensor type with the best average selectivity was the Pt/ PEA/PPD/BSA/GluOx electrode produced by electropolymerisation in $300 \mathrm{mmol} \mathrm{l}^{-1} \mathrm{PD}$ for $15-30 \mathrm{~min}: S_{\mathrm{AA}}=84 \pm 9 \%(n$ $=11$ ) for $10 \mu \mathrm{mol} \mathrm{l}^{-1} \mathrm{Glu}$ and $500 \mu \mathrm{mol} 1^{-1}$ AA. For use in a given application, however, electrodes can be chosen that have the best characteristics. For example, half of the total sample of 11 electrodes gave $S_{\mathrm{AA}}=92 \pm 3 \%(n=5)$. This sensor design (see Fig. 1) may therefore be suitable for neurochemical studies and therefore further characterisation was carried out in vitro.

The response time to Glu was of the order of the mixing time in the cell (about $10 \mathrm{~s}$, see Fig. 2), i.e., similar to Pt/PPD/GOx electrodes ${ }^{33-39}$ but much faster than sensors incorporating PEA by the drop coating technique. ${ }^{45}$ The sensitivity was high in the linear range $\left(0-100 \mu \mathrm{mol} 1^{-1} \mathrm{Glu}, 3.8 \pm 1.3 \mathrm{nA} \mathrm{cm}^{-2} \mu \mathrm{mol}^{-1}\right.$ $\left.1, r^{2}=0.99 \pm 0.01, n=4\right)$ with a low LOD $(2 \times s$ of baseline, see Table 1). Glutamine, a possible source of interference with an ECF level in the region of $100 \mu \mathrm{mol} 1^{-1}, 53,54$ had no effect on the sensor's response up to $1 \mathrm{mmol}^{-1}$ (see Fig. 2). These properties compare favourably with those of other GluOx-based sensors in the literature. $16,17,20$

Fig. 2 (inset) shows a typical response of a Pt/PEA/PPD/ BSA/ GluOx electrode to $500 \mu \mathrm{mol}^{-1} \mathrm{AA}$. The average size of the response was small $(0.14 \pm 0.12 \mathrm{nA}$; see Table 1$)$, representing an approximately 2500 -fold decrease in sensitivity compared with bare Pt. Taken with the slow response time (about $2 \mathrm{~min}$ ), the data indicate that the PEA and PPD films offer a significant barrier to AA diffusion to the Pt surface (see Fig. 1).

AA has been shown to interfere with biosensors by another mechanism, i.e., a homogeneous reaction with hydrogen peroxide that decreases the sensors' response to substrate. ${ }^{39}$ Normally this reaction is too slow to be a problem, 55,56 but it can be catalysed by heavy metal ions ${ }^{57}$ or peroxidases. ${ }^{58}$ Thus, trace metal impurities in the buffer can lead to negative interference by AA in vitro, but the effect can be blocked by the incorporation of EDTA in the buffer. ${ }^{39}$ Since AA has been shown to decrease the response to Glu of a GluOx-based assay, ${ }^{32}$ Glu responses were recorded in the presence and absence of AA $\left(500 \mu \mathrm{mol} \mathrm{l}^{-1}\right)$ plus EDTA $\left(1 \mathrm{mmol} \mathrm{l}^{-1}\right)$; there was no difference in Glu sensitivity under the two conditions (data not shown). This mode of interference by AA is also 
Table 2 Comparison of the sensitivity of bare $\mathrm{Pt}$ and $\mathrm{Pt} / \mathrm{PEA} / \mathrm{PPD} / \mathrm{BSA} /$ GluOx electrodes to some electroactive substances (other than AA) found in brain ECF. The ECF levels are estimated baseline concentrations. ${ }^{52}$ The responses at ECF levels for Pt/PEA/PPD/BSA/GluOx sensors are estimated from the calibration data

\begin{tabular}{|c|c|c|c|c|}
\hline Substance & $\begin{array}{c}\text { Sensitivity } \\
\text { bare } \mathrm{Pt} / \\
\mathrm{nA} \mu \mathrm{mol}^{-1} 1\end{array}$ & $\begin{array}{c}\text { Sensitivity } \\
\text { Pt/PEA/PPD/ } \\
\text { BSA/GluOx/ } \\
\text { pA } \mu \mathrm{mol}^{-1} 1\end{array}$ & $\begin{array}{c}\text { ECF level/ } \\
\mu \mathrm{mol} 1^{-1}\end{array}$ & $\begin{array}{c}\text { Response at } \\
\text { ECF levels/ } \\
\text { pA }\end{array}$ \\
\hline DA & $\begin{array}{c}1.0 \pm 0.1 \\
(n=4)\end{array}$ & $\begin{array}{c}16 \pm 1 \\
(n=3)\end{array}$ & 0.05 & 1 \\
\hline DOPAC & $\begin{array}{c}0.5 \pm 0.1 \\
(n=4)\end{array}$ & $\begin{array}{c}3.3 \pm 0.3 \\
(n=3)\end{array}$ & 10 & 35 \\
\hline UA & $\begin{array}{c}0.5 \pm 0.1 \\
(n=4)\end{array}$ & $\begin{array}{c}3.7 \pm 0.5 \\
(n=4)\end{array}$ & 5 & 20 \\
\hline
\end{tabular}

absent in brain tissue, presumably owing to the absence of suitable catalysts. ${ }^{39}$

Table 2 shows the response to a variety of other interfering substances found in brain ECF. Modification of the Pt with the PEA/PPD/BSA film (Fig. 1) reduced its sensitivity to DA, DOPAC and UA about 100 fold, and the responses were linear in the low concentration ranges tested. At the levels of these species found in the ECF, the corresponding current (see Table 2 ) would be negligible compared with the $10 \mu \mathrm{mol} 1^{-1}$ Glu signal ( $>1 \mathrm{nA}$, see Table 1). Interference by UA is complicated by the finding that its concentration in brain ECF depends on the size of the electrode ${ }^{59}$ but for sensors of the size used here, UA concentrations would be $<5 \mu \mathrm{mol} 1^{-1}$. Thus, although the presence of AA (and not other endogenous species, such as $\mathrm{DA}^{17}$ ) is the most significant limitation for the application of biosensors in brain tissue, the selectivity of the Pt/PEA/PPD/ BSA/GluOx electrode developed here suggests suitability for neurochemical applications in vivo. A more complicated combination of Nafion, ascorbate oxidase, cellulose acetate, glutaraldehyde, BSA and GluOx has been used in one study to produce a sensor with an equivalent $S_{\mathrm{AA}}$ of about $99 \% ; 16$ however, there has been a paucity of reports on applications using this sensor in the years since its first appearance.

\section{Conclusions}

The relatively simple fabrication of a sensor for Glu, based on the efficient use of GluOx, has been described. The sensor has high sensitivity for substrate and sufficient selectivity to provide a basis for neurochemical applications in vivo. Detailed characterisation remains to be carried out in brain tissue in vivo, however, before the sensor can be used to monitor Glu unambiguously in the ECF.

We thank Dr. H. Kusakabe (Yamasa Shoyu Co., Japan) for the generous gift of L-glutamate oxidase. We are grateful to University College Dublin for financial support. JPL is a Marie Curie Fellow (Contract No. ERB FMB ICT 961319).

\section{References}

1 Fillenz, M., Behav. Brain Res., 1995, 71, 51.

2 Obrenovitch, T. P., and Urenjak, J., Prog. Neurobiol., 1997, 51, 39.

3 Conn, P. J., and Pin, J. P., Annu. Rev. Pharmacol. Toxicol., 1997, 37, 205.

4 Hazell, A. S., Butterworth, R. F., and Hakim, A. M., J. Neurochem., 1993, 61, 1155.

5 O'Shea, T. J., Weber, P. L., Bammel, B. P., Lunte, C. E., Lunte, S. M., and Smyth, M. R., J. Chromatogr., 1992, 608, 189.

6 Choi, K. T., Illievich, U. M., Zornow, M. H., Scheller, M. S., and Strnat, M. A. P., Brain Res., 1994, 642, 104.
7 Miele, M., Berners, M., Boutelle, M. G., Kusakabe, H., and Fillenz, M., Brain Res., 1996, 707, 131.

8 Lada, M. W., and Kennedy, R. T., Anal. Chem., 1996, 68, 2790.

9 Herrera-Marschitz, M., You, Z. B., Goiny, M., Meana, J. J., Silveira, R., Godukhin, O. V., Chen, Y., Espinoza, S., Pettersson, E., Loidl, C. F., Lubec, G., Andersson, K., Nylander, I., Terenius, L., and Ungerstedt, U., J. Neurochem., 1996, 66, 1726.

10 Bogdanov, M. B., Tjurmina, O. A., and Wurtman, R. J., Brain Res., 1996, 736, 76.

11 Miele, M., Boutelle, M. G., and Fillenz, M., J. Physiol. (London), 1996, 497, 745 .

12 Meeusen, R., Smolders, I., Saare, S., De Meirleir, K., Keizer, H., Serneels, M., Ebinger, G., and Michotte, Y., Acta Physiol. Scand., 1997, 159, 335.

13 Lowry, J. P., and Fillenz, M., J. Physiol. (London), 1997, 498, 497.

14 Garguilo, M. G., and Michael, A. C., Anal. Chem., 1994, 66, 2621.

15 Albery, W. J., Boutelle, M. G., and Galley, P. T., J. Chem. Soc. Chem. Commun., 1992, 900.

$16 \mathrm{Hu}$, Y., Mitchell, K. M., Albahadily, F. N., Michaelis, E. K., and Wilson, G. S., Brain Res., 1994, 659, 117.

17 Cooper, J. M., Foreman, P. L., Glidle, A., Ling, T. W., and Pritchard, D. J., J. Electroanal. Chem., 1995, 388, 143.

18 Montagne, M., Durliat, H., and Comtat, M., Anal. Chim. Acta, 1993, 278, 25.

19 Mulchandani, A., and Wang, C. L., Electroanalysis, 1996, 8, 414.

20 Cosnier, S., Innocent, C., Allien, L., Poitry, S., and Tsacopoulos, M., Anal. Chem., 1997, 69, 968.

21 Kusakabe, H., Midorikawa, Y., Fujishima, T., Kuninaka, A., and Yoshino, H., Agric. Biol. Chem., 1983, 47, 1323.

22 Matsumoto, K., Sakoda, K., and Osajima, Y., Anal. Chim. Acta, 1992, 261, 155.

23 Boutelle, M. G., Fellows, L. K., and Cook, C., Anal. Chem., 1992, 64, 1790.

24 Cooper, J. M., and Pritchard, D. J., J. Mater. Sci., 1994, 5, 111

25 White, S. F., Turner, A. P. F., Bilitewski, U., Schmid, R. D., and Bradley, J., Anal. Chim. Acta, 1994, 295, 243.

26 Walker, M. C., Galley, P. T., Errington, M. L., Shorvon, S. D., and Jefferys, J. G. R., J. Neurochem., 1995, 65, 725.

27 Zilkha, E., Obrenovitch, T. P., Koshy, A., Kusakabe, H., and Bennetto, H. P., J. Neurosci. Methods, 1995, 60, 1.

28 Yoshida, S., Kanno, H., and Watanabe, T., Anal. Sci., 1995, 11, 251.

29 Li, Q. S., Zhang, S. L., and Yu, J. T., Appl. Biochem. Biotechnol., 1996, 59, 53.

30 Yao, T., Suzuki, S., Nishino, H., and Nakahara, T., Electroanalysis, 1996, 7, 1114.

31 Blankenstein, G., Preuschoff, F., Spohn, U., Mohr, K. H., and Kula, M. R., Anal. Chim. Acta, 1993, 271, 231.

32 Stalikas, C. D., Karayannis, M. I., and Tzouwara-Karayanni, S. M. Analyst, 1993, 118, 723.

33 Sasso, S. V., Pierce, R. J., Walla, R., and Yacynych, A. M., Anal. Chem., 1990, 62, 1111.

34 Malitesta, C., Palmisano, F., Torsi, L., and Zambonin, P. G., Anal. Chem., 1990, 62, 2735.

35 Almeida, N. F., Wingard, L. B., Jr. and Malmros, M. K., Ann. NY Acad. Sci., 1990, 613, 448.

36 Sohn, T. W., Stoecker, P. W., Carp, W., and Yacynych, A. M., Electroanalysis, 1991, 3, 763.

37 Reynolds, E. R., and Yacynych, A. M., Electroanalysis, 1993, 5, 405.

38 Bartlett, P. N., and Birkin, P. R., Anal. Chem., 1994, 66, 1552.

39 Lowry, J. P., McAteer, K., El Atrash, S. S., Duff, A., and O'Neill, R. D., Anal. Chem., 1994, 66, 1754.

40 Lowry, J. P., and O’Neill, R. D., Electroanalysis, 1994, 6, 369.

41 Amatore, C., Kelly, R. S., Kristensen, E. W., Kuhr, W. G., and Wightman, R. M., J. Electroanal. Chem., 1986, 213, 31.

42 Miele, M., and Fillenz, M., J. Neurosci. Methods, 1996, 70, 15

43 Bartlett, P. N., and Whitaker, R. G., J. Electroanal. Chem., 1987, 224, 37.

44 Bartlett, P. N., and Caruana, D. J., Analyst, 1992, 117, 1287.

45 McAteer, K., and O’Neill, R. D., Analyst, 1996, 121, 773.

46 Wang, J., and Wu, H., Anal. Chim. Acta, 1993, 283, 683.

47 El Atrash, S. S., and O’Neill, R. D., Electrochim. Acta, 1995, 40, 2791 
48 Ohnuki, Y., Matsuda, H., Ohsaka, T., and Oyama, N., J. Electroanal. Chem., 1983, 158, 55.

49 Wilson, G. S., and Thevenot, D. R., in Biosensors: A Practical Approach, ed. Cass, A. E. G., Oxford University Press, New York, 1990, pp 1-17.

50 Blaha, C. D., and Phillips, A. G., Behav. Pharmacol., 1996, 7, 675.

51 Lyne, P. D., and O'Neill, R. D., Anal. Chem., 1990, 62, 2347.

52 O'Neill, R. D., Analyst, 1994, 119, 767.

53 Palmer, A. M., Marion, D. W., Botscheller, M. L., Swedlow, P. E., Styren, S. D., and DeKosky, S. T., J. Neurochem., 1993, 61, 2015.

54 De Knegt, R. J., Schalm, S. W., Van der Rijt, C. C. D., Fekkes, D., Dalm, E., and Hekking-Weyma, I., J. Hepatol., 1994, 20, 19.
55 Centonze, D., Guerrieri, A., Palmisano, F., Torsi, L., and Zambonin, P. G., Fresenius' J. Anal. Chem., 1994, 349, 497.

56 Losito, I., and Zambonin, C. G., J. Electroanal. Chem., 1996, 410, 181.

57 Hand, D. B., and Greisen, E. C., J. Am. Chem. Soc., 1942, 64, 358.

58 Frank, J., Holzwarth, J. F., and Dunford, H. B., J. Chem. Soc. Faraday Trans., 1994, 90, 3201.

59 Duff, A., and O'Neill, R. D., J. Neurochem., 1994, 62, 1496.

Paper 7/04508E

Received June 26, 1997 Accepted August 27, 1997 